\title{
An ultraviolet responsive hybrid solar cell based on titania/poly(3-hexylthiophene)
}

SUBJECT AREAS:

APPLIED PHYSICS

SOLAR CELLS

ENERGY TRANSFER

ELECTRONIC MATERIALS

Received

10 November 2012

Accepted

25 January 2013

Published

15 February 2013

Correspondence and requests for materials should be addressed to

J.H.W. (jhwu@hqu. edu.cn)
Jihuai Wu', Gentian Yue', Yaoming Xiao', Jianming Lin', Miaoliang Huang' ', Zhang Lan', Qunwei Tang', Yunfang Huang', Leqing Fan', Shu Yin ${ }^{2} \&$ Tsugio Sato ${ }^{2}$

${ }^{1}$ Engineering Research Center of Environment-Friendly Functional Materials, Ministry of Education, Institute of Materials Physical Chemistry, Huaqiao University, Quanzhou 362021, Fujian, P. R. China, ${ }^{2}$ Institute of Multidisciplinary Research for Advanced Materials, Tohoku University, Sendai 980-8577, Japan.

Here we present an ultraviolet responsive inorganic-organic hybrid solar cell based on titania/ poly(3-hexylthiophene) $\left(\mathrm{TiO}_{2} / \mathrm{P} 3 \mathrm{HT}\right)$ heterojuction. In this solar cell, $\mathrm{TiO}_{2}$ is an ultraviolet light absorber and electronic conductor, $\mathrm{P} 3 \mathrm{HT}$ is a hole conductor, the light-to-electrical conversion is realized by the cooperation for these two components. Doping ionic salt in P3HT polymer can improve the photovoltaic performance of the solar cell. Under ultraviolet light irradiation with intensity of $100 \mathrm{~mW} \cdot \mathrm{cm}^{-2}$, the hybrid solar cell doped with 1.0 wt.\% lithium iodide achieves an energy conversion efficiency of $1.28 \%$, which is increased by $33.3 \%$ compared to that of the hybrid solar cell without lithium iodide doping. Our results open a novel sunlight irradiation field for solar energy utilization, demonstrate the feasibility of ultraviolet responsive solar cells, and provide a new route for enhancing the photovoltaic performance of solar cells.

olar energy has been considered as a green and renewable alternative energy source to traditional fossil fuels ${ }^{1}$. Solar cell is an attractive photovoltaic device for producing electrical energy directly from sunlight, without producing noise, toxic substance and greenhouse gas emission ${ }^{2}$. In various solar cells, the utilized solar radiation is mainly in visible light range, which occupies the largest part of solar radiation from the sun to the earth. However, ultraviolet light is few to be utilized in various solar cells. Although the ultraviolet light flux from the sun to the earth is small, the photon energy for the ultraviolet light is high ${ }^{1-3}$. The development of ultraviolet responsive solar cell is very significant in theory and actual application for photovoltaic and photoelectric devices. Unfortunately, no ultraviolet responsive solar cell has been reported so far.

\section{Results}

The design of an ultraviolet responsive solar cell. In order to devise the solar cell, it needs to choose a suitable ultraviolet light absorber. As we know that titania $\left(\mathrm{TiO}_{2}\right)$ possesses a unique structure and wonderful properties, which has emerged as excellent photocatalytic and photoelectric materials ${ }^{3-5}$. Titania can not only harvest ultraviolet light with wavelength shorter than $380 \mathrm{~nm}$, but also is an n-type semiconductor, which can be used as an electron acceptor offering a pathway for electronic transmission in solar cells ${ }^{3}$. On the other hand, poly(3hexylthiophene) (P3HT) and poly(3-octylthiophene-2, 5-diyl) (P3OT) as key materials in polymer solar cells have recently aroused wide attentions ${ }^{6-8}$. $\mathrm{P} 3 \mathrm{HT}$ is a p-type semiconductor polymer and has high hole mobility $\left(10^{-4} \sim 10^{-2} \mathrm{~cm}^{2} \mathrm{~V}^{-1} \mathrm{~s}^{-1}\right)$; it is usually used as an electron donor in polymer solar cells. Combining these two primary components of $\mathrm{TiO}_{2}$ and $\mathrm{P} 3 \mathrm{HT}$, an ultraviolet responsive inorganic-organic hybrid solar cell is designed. According to references ${ }^{3,9,10}$, the LUMO/HOMO energy levels of P3HT, P3OT and $\mathrm{TiO}_{2}$ are about $-3.53 /-5.20$, $-2.85 /-5.25$ and $-4.2 /-7.4$ (eV vs Vacuum), respectively. Under ultraviolet photoexcitation, electron-hole pairs are created in the $\mathrm{TiO}_{2}$ semiconductor and then are dissociated into free charge carriers (electrons and holes). The electrons are transferred to the conducting glass substrate (FTO) via $\mathrm{TiO}_{2}$ grid; the holes are reduced by electron donation from the valence band of $\mathrm{P} 3 \mathrm{HT}$ and then from the platinum-plated (Pt) counter electrode, with the circuit being completed via electron migration through the external load. Overall, the device generates electric power from ultraviolet light without suffering any permanent chemical transformation. Fig. $1 \mathrm{~B}$ shows the schematic energy levels of the components and the photoelectric conversion process.

Phase and morphology. The $\mathrm{X}$-ray diffraction (XRD) pattern of prepared $\mathrm{TiO}_{2}$ is shown in Fig. $2 \mathrm{~A}$, the scanning electron microscope (SEM) images of $\mathrm{TiO}_{2}, \mathrm{TiO}_{2} / \mathrm{P} 3 \mathrm{HT}$ and $\mathrm{TiO}_{2} /$ glass (cross sectional) are shown in Figs. 2B, 2C and $2 \mathrm{D}$. It can be seen that the prepared $\mathrm{TiO}_{2}$ is pure anatase phase, the particle size is about $50 \mathrm{~nm}$, and the $\mathrm{TiO}_{2}$ 


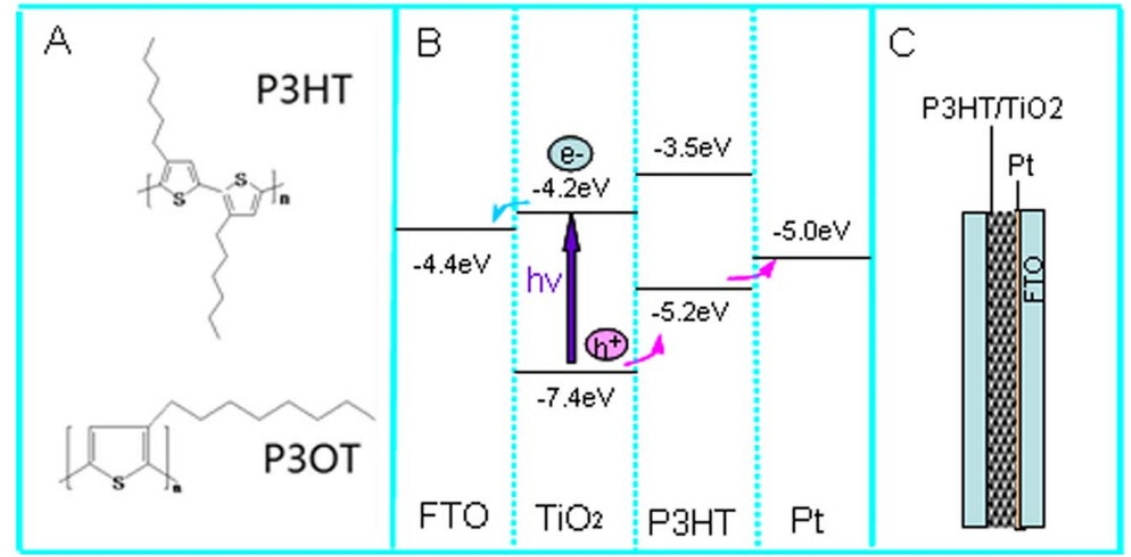

Figure 1 The schematic diagram of P3HT and P3OT (A), the energy level for the hybrid solar cell (B), and the hybrid solar cell (C).

is soaked and coated with P3HT. The interface between $\mathrm{TiO}_{2}$ and glass is clear, which will lead to the interfacial transfer resistance of carriers.

The UV-vis and infrared spectra analysis. The UV-vis absorption spectra of $\mathrm{TiO}_{2}, \mathrm{P} 3 \mathrm{HT}, \mathrm{P} 3 \mathrm{OT}, \mathrm{P} 3 \mathrm{HT} / \mathrm{TiO}_{2}, \mathrm{P} 3 \mathrm{OT} / \mathrm{TiO}_{2}$ were measured and are displayed in Fig. 3. As expected, $\mathrm{TiO}_{2}$ has no absorption band in visible range and shows the characteristic spectrum with its fundamental absorption of $\mathrm{Ti}-\mathrm{O}$ bond in ultraviolet light range from 320 to $400 \mathrm{~nm}$. From the spectrum of the $\mathrm{P} 3 \mathrm{HT} / \mathrm{TiO}_{2}$, it can be seen the two absorption bands in ultraviolet light region and in visible light region, respectively. The former band from 320 to $400 \mathrm{~nm}$ is assigned to the characteristic absorption of $\mathrm{TiO}_{2}$. The latter band with a peak wavelength of $510 \mathrm{~nm}$ is attributed to the electron transition $\left(\pi-\pi^{*}, 2.43 \mathrm{eV}\right)$ from the valence bond (HOMO) to the conduction band (LUMO) of P3HT. Similarly, the $\mathrm{P} 3 \mathrm{OT} / \mathrm{TiO}_{2}$ also has two absorption bands: one band is for the $\mathrm{TiO}_{2}$, the other band with peak wavelength of $540 \mathrm{~nm}$ is for the electron transition $\left(\pi-\pi^{*}, 2.30 \mathrm{eV}\right)$ from the HOMO to the LUMO of P3OT. In addition, it is notable that the absorption band of $\mathrm{P} 3 \mathrm{HT} / \mathrm{TiO}_{2}$ is stronger and wider than that of $\mathrm{P} 3 \mathrm{OT} / \mathrm{TiO}_{2}$, which is due to the fact that with the alkyl carbon chain increase in thiophene ring
A
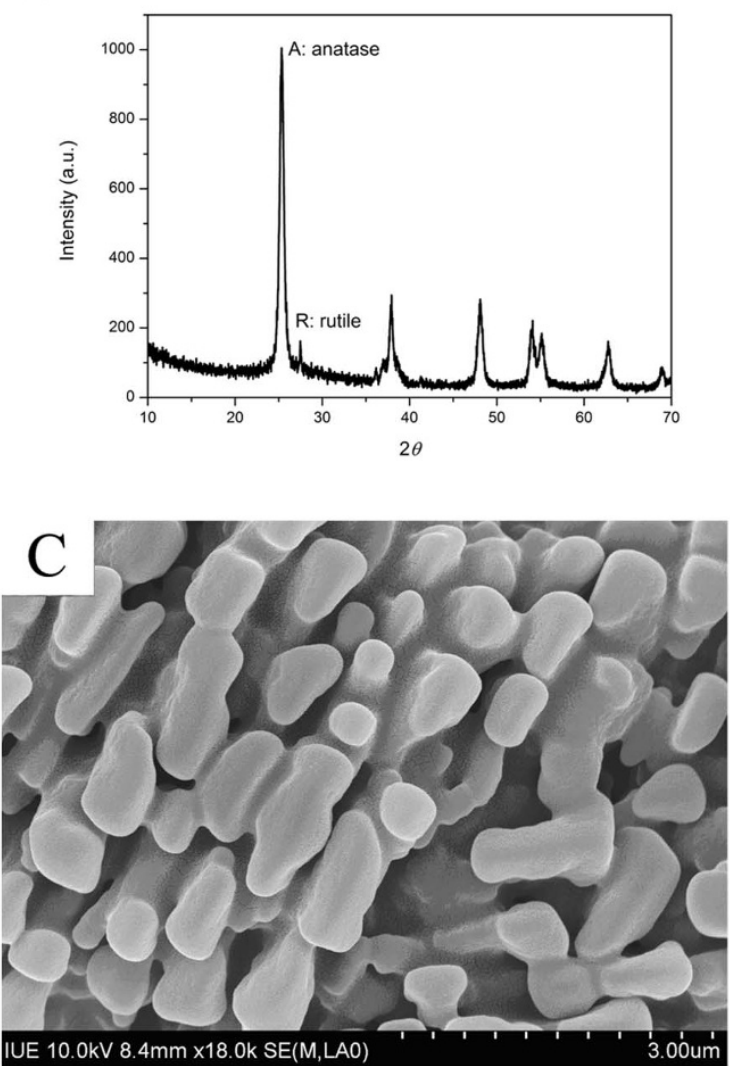
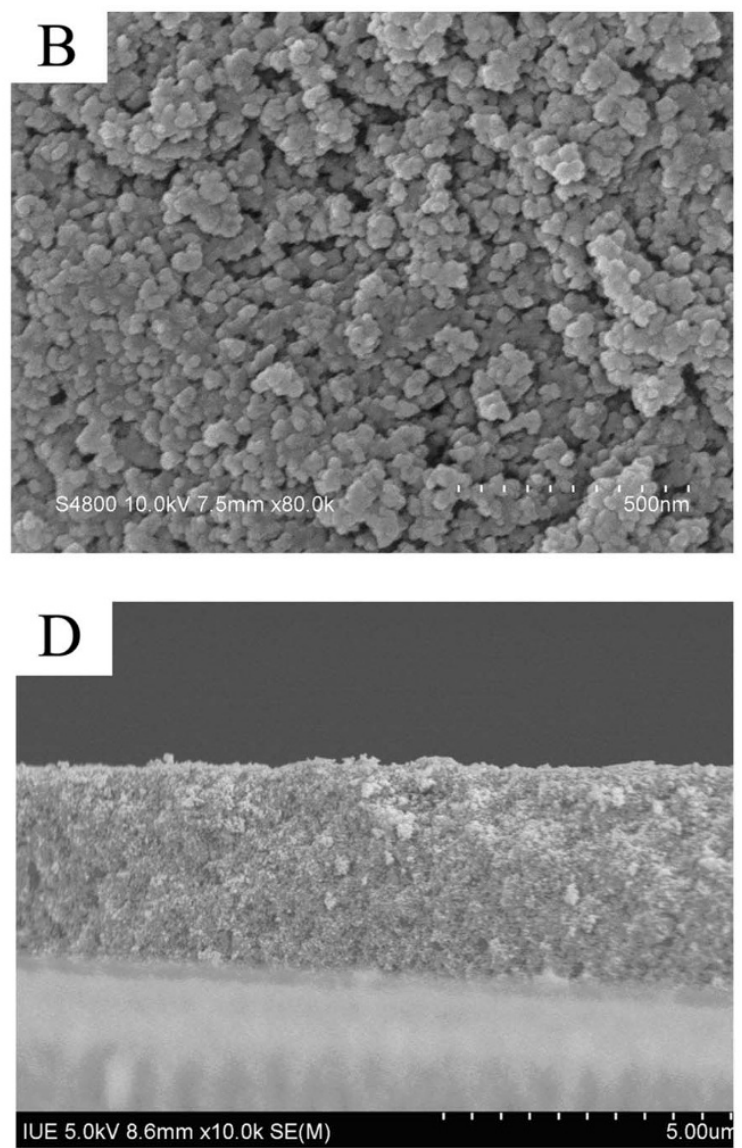

Figure $2 \mid$ The XRD spectrum of prepared $\mathrm{TiO}_{2}(\mathrm{~A})$, SEM image of prepared $\mathrm{TiO}_{2}(\mathrm{~B})$, SEM image of $\mathrm{TiO}_{2} / \mathrm{P} 3 \mathrm{HT}(\mathrm{C})$, and cross sectional SEM image of $\mathrm{TiO}_{2} /$ glass (D). 


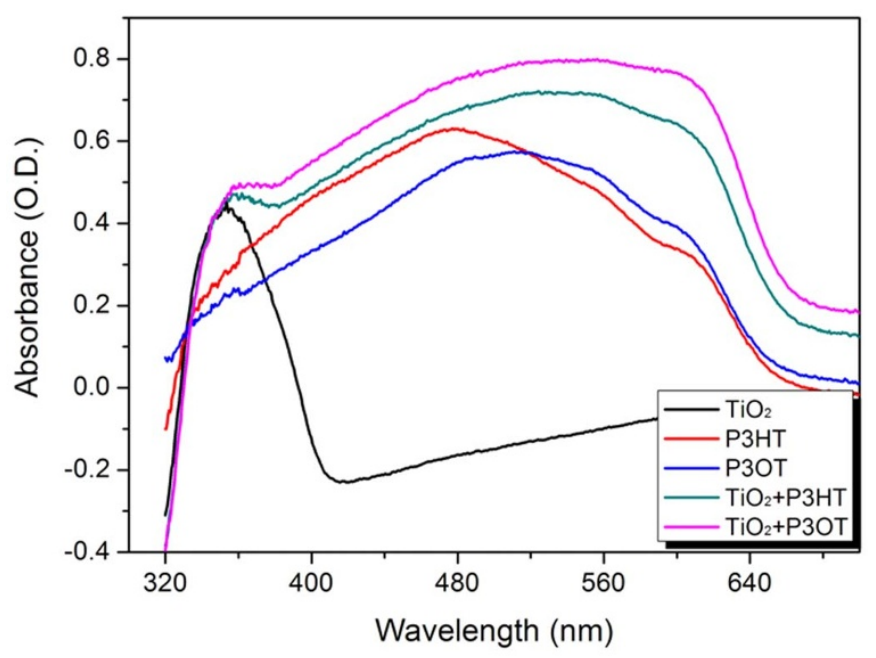

Figure 3 The UV-vis absorption spectra of $\mathrm{TiO}_{2}$, P3OT, P3HT, P3OT/ $\mathrm{TiO}_{2}$, and $\mathrm{P} 3 \mathrm{HT} / \mathrm{TiO}_{2}$.

3-substituted (Fig. 1A), the polymer ionization energy decrease, leading to the lower band gap energy for the P3OT than $\mathrm{P} 3 \mathrm{HT}^{11}$.

Fig. 4 shows the Fourier transform infrared (FTIR) spectra of $\mathrm{TiO}_{2}, \mathrm{P} 3 \mathrm{HT}, \mathrm{P} 3 \mathrm{OT}, \mathrm{P} 3 \mathrm{HT} / \mathrm{TiO}_{2}$ and P3OT/TiO 2 . The curves of both P3HT and P3OT have similar absorption bands, since they have a similar structure and similar groups (Fig. 1A). In their spectra, there is a low-intensity peak at about $3056 \mathrm{~cm}^{-1}$, which is attributed to the thiophene ring $\mathrm{C}_{\beta}-\mathrm{H}$ stretching vibration. The three peaks at 2850 $2958 \mathrm{~cm}^{-1}$ are for the $\mathrm{C}-\mathrm{H}$ bond asymmetric and symmetric stretching vibration. The peak at $1510 \mathrm{~cm}^{-1}$ corresponds to thiophene ring $\mathrm{C}=\mathrm{C}$ stretching vibration. The peaks at 1456 and $1377 \mathrm{~cm}^{-1}$ are due to the asymmetric and symmetric deformation vibrations of $\mathrm{C}-\mathrm{H}$ bond. The peak at $823 \mathrm{~cm}^{-1}$ is attributed to the $\mathrm{C}-\mathrm{H}$ vibration out-of-plane of the thiophene ring. The peak at $725 \mathrm{~cm}^{-1}$ is the characteristic absorption of $S$ atom on the polythiophene ring. These are the characteristic peaks for P3HT and $\mathrm{P}_{3} \mathrm{OT}^{12,13}$. In $\mathrm{TiO}_{2}$ spectrum, there is no obvious absorption in visible and infrared range from 500 to $3500 \mathrm{~cm}^{-1}$. A weak absorption peak at $1627 \mathrm{~cm}^{-1}$ belongs to the $\mathrm{O}-\mathrm{H}$ bending vibration of the absorbed $\mathrm{H}_{2} \mathrm{O}$ on the $\mathrm{TiO}_{2}$ surface. Owing to small amount of P3OT and $\mathrm{P} 3 \mathrm{HT}$ in the $\mathrm{P} 3 \mathrm{OT} / \mathrm{TiO}_{2}$ and $\mathrm{P} 3 \mathrm{HT} / \mathrm{TiO}_{2}$, the absorption peaks for

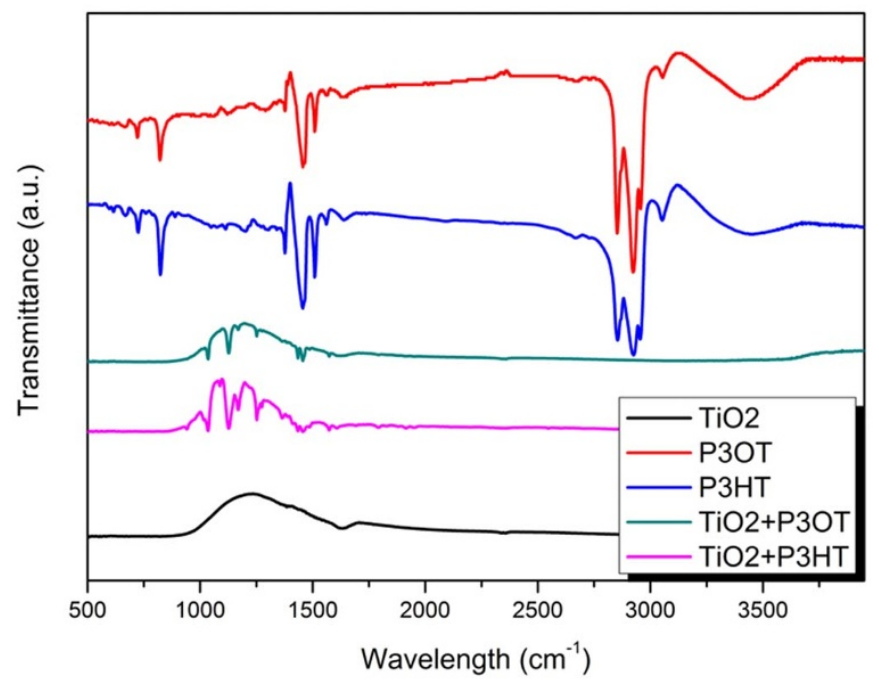

Figure $4 \mid$ Fourier transform infrared spectra of $\mathrm{TiO}_{2}$, P3OT, P3HT, $\mathrm{P} 3 \mathrm{OT} / \mathrm{TiO}_{2}$, and $\mathrm{P} 3 \mathrm{HT} / \mathrm{TiO}_{2}$.
P3HT and P3OT are suppressed. There is no obvious absorption for the $\mathrm{P} 3 \mathrm{HT}$ in the $\mathrm{P} 3 \mathrm{HT} / \mathrm{TiO}_{2}$ and the $\mathrm{P} 3 \mathrm{OT}$ in $\mathrm{P} 3 \mathrm{OT} / \mathrm{TiO}_{2}$.

The photovoltaic performance of the hybrid solar cell. Fig. 5A shows the monochromatic incident photo-to-electron conversion efficiency (IPCE) curves for the hybrid solar cells with $\mathrm{P} 3 \mathrm{HT} / \mathrm{TiO}_{2}$, P3OT/TiO 2 and $\mathrm{TiO}_{2}$, respectively. Three solar cells show strong photoelectric response to ultraviolet light ranged from 300 to $400 \mathrm{~nm}$, and the highest IPCE value of $23.59 \%$ at $350 \mathrm{~nm}$ is obtained by the solar cell based on $\mathrm{P} 3 \mathrm{HT} / \mathrm{TiO}_{2}$. The IPCE value in ultraviolet range is mainly caused by the strong absorption of $\mathrm{TiO}_{2}$, since $\mathrm{TiO}_{2}$ has an absorption peak around $350 \mathrm{~nm}$ for the direct band gap photo-electron excitation ${ }^{14}$. The IPCE values decrease in the order: $\mathrm{P} 3 \mathrm{HT} / \mathrm{TiO}_{2}, \mathrm{P} 3 \mathrm{OT} / \mathrm{TiO}_{2}$, pristine $\mathrm{TiO}_{2}$, which is accorded with the absorption intensity order in ultraviolet range shown in the Fig. 3, indicating that the photoelectric conversion can be achieved through the excitation of $\mathrm{TiO}_{2}$. The IPCE peak values for the cells with $\mathrm{P} 3 \mathrm{HT} / \mathrm{TiO}_{2}$ and $\mathrm{P} 3 \mathrm{OT} / \mathrm{TiO}_{2}$ films are higher than that of pristine $\mathrm{TiO}_{2}$ film in ultraviolet range, which is due to that the P3HT and P3OT can harvest ultraviolet light and improve carrier transportation function ${ }^{15}$. Furthermore, the higher IPCE value for $\mathrm{P} 3 \mathrm{HT} / \mathrm{TiO}_{2}$ than that of $\mathrm{P} 3 \mathrm{OT} / \mathrm{TiO}_{2}$ results from the better conductivity of P3HT than P3OT (shown in Fig. 6), which is ready for the better photovoltaic performance for the solar cell based on $\mathrm{P} 3 \mathrm{HT} / \mathrm{TiO}_{2}$ than that for the solar cell based on $\mathrm{P} 3 \mathrm{OT} / \mathrm{TiO}_{2}$.

The photovoltaic performances of the hybrid solar cells were determined by measuring photocurrent-photovoltage $(J-V)$ characteristic curves under ultraviolet light irradiation. Fig. 5B shows the $J-V$ curves for the hybrid solar cells with $\mathrm{P} 3 \mathrm{HT} / \mathrm{TiO}_{2}$ containing $1.0 \mathrm{wt} . \%$ of LiI under ultraviolet light irradiation with different intensities. It can be seen that, with the increase of the irradiated ultraviolet light intensity, the short-circuit current density $\left(J_{S C}\right)$ of the hybrid solar cell increases, the open-circuit voltage $\left(V_{O C}\right)$ and fill factor $(F F)$ are kept in about $0.9 \mathrm{~V}$ and 0.56 , respectively. Under the ultraviolet light irradiation of $100 \mathrm{~mW} \cdot \mathrm{cm}^{-2}$, the solar cell achieves the best photovoltaic performance, the $J_{S C}$ reaches $2.50 \mathrm{~mA} \cdot \mathrm{cm}^{-2}$ and the light-to-electrical energy conversion efficiency $(\eta)$ reaches $1.28 \%$.

The influence of doping polymer on the performance of the hybrid solar cells. It is said that the photovoltaic performance of the solar cells can be improved by doping appropriate ions in P3HT or P3OT polymer ${ }^{16,17}$. Many kinds of inorganic ions, such as $\mathrm{Cl}^{-}, \mathrm{Br}^{-}, \mathrm{F}^{-}$, $\mathrm{NO}_{3}{ }^{-}, \mathrm{ClO}_{4}{ }^{-}, \mathrm{BF}_{4}^{-}$and $\mathrm{HSO}_{4}^{-}$ions ${ }^{18}$, have been attempted to improve the conductivity of the polymers. The conductivities of P3HT and P3OT solutions containing different LiI amounts were measured and shown in Fig. 6. With the increase of the amount of LiI doped, the conductivities of P3HT and P3OT systems increase linearly until the LiI content reaches $1.0 \mathrm{wt} . \%$, and then rise gently. Singh et $a l^{19}$ had confirmed that the conductivity improvement by doping inorganic ions in $\mathrm{P} 3 \mathrm{HT}$ film originated from the ions hopping process. The improvement of conductivities of $\mathrm{P} 3 \mathrm{HT}$ and P3OT systems is ready for the enhancement of the photovoltaic performance of hybrid solar cells.

The photovoltaic parameters of the hybrid solar cells based on $\mathrm{P} 3 \mathrm{HT} / \mathrm{TiO}_{2}$ and $\mathrm{P} 3 \mathrm{OT} / \mathrm{TiO}_{2}$ containing $\mathrm{KI}$ or $\mathrm{LiI}$ were measured and summarized in Table 1. It can be seen that with the increase of doping ion amount, the $V_{O C}$ and $F F$ values of the hybrid solar cells stay unvaried, the $J_{S C}$ values increase, which results in the $\eta$ value increase. The $J_{S C}$ improvement is due to the change of conductivity of the polymer systems. It is notable that the $J_{S C}$ and $\eta$ values of the solar cells containing LiI are higher than those of the solar cells containing KI with a same concentration, which indicates that LiI has a better effect than KI on improving the photovoltaic performance of the solar cells. The $\eta$ values for the hybrid solar cells based on P3HT/ $\mathrm{TiO}_{2}$ and $\mathrm{P} 3 \mathrm{OT} / \mathrm{TiO}_{2}$ doped with $1.0 \mathrm{wt} . \% \mathrm{LiI}$ are $1.28 \%$ and $1.16 \%$, which are increased by $33.3 \%$ and $32.1 \%$, respectively, compared to 

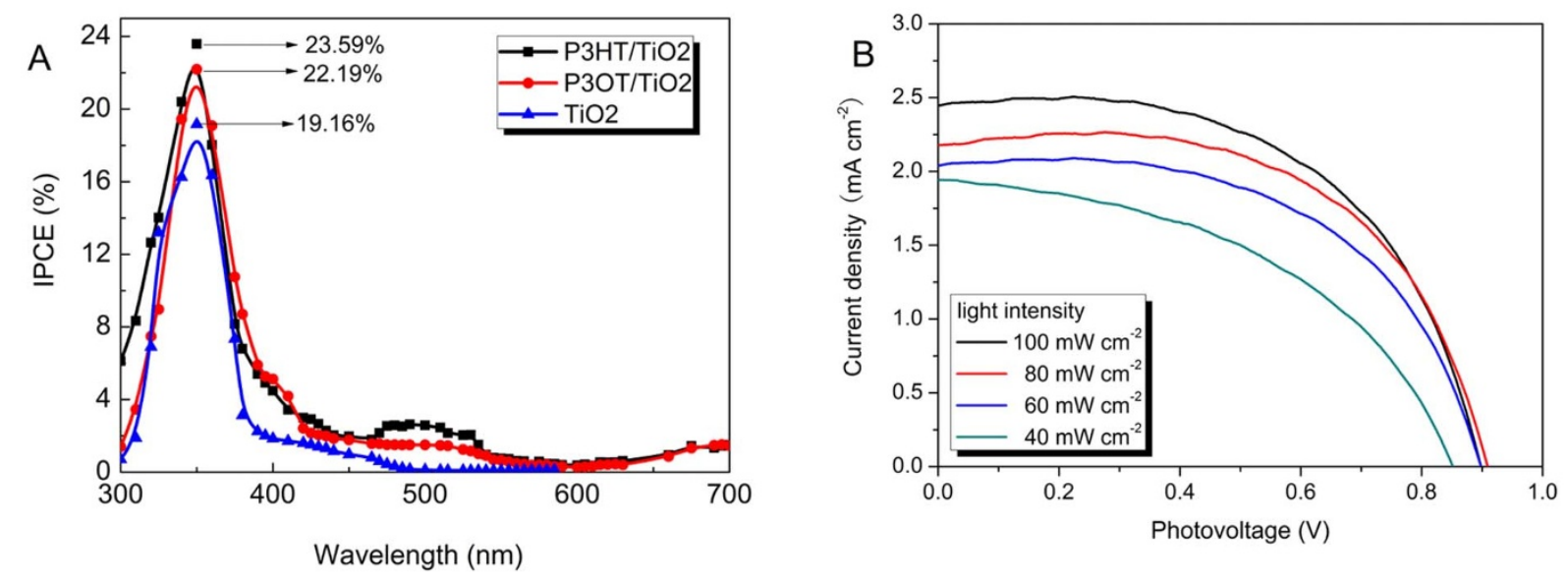

Figure 5 | The IPCE curves for the solar cells with $\mathrm{P} 3 \mathrm{HT} / \mathrm{TiO}_{2}, \mathrm{P} 3 \mathrm{OT} / \mathrm{TiO}_{2}$, and $\mathrm{TiO}_{2}(\mathrm{~A})$; The $\mathrm{J}-\mathrm{V}$ curves of the hybrid solar cell with $\mathrm{P} 3 \mathrm{HT} / \mathrm{TiO}{ }_{2}$ under ultraviolet irradiation with different intensities (B).

those of the hybrid solar cells without LiI doping. We believe that the photovoltaic performance of ultraviolet responsive solar cell will be further improved by optimizing preparation conditions.

Stability of hybrid solar cells. Fig. 7 shows the stability of the hybrid solar cells with $\mathrm{P} 3 \mathrm{HT} / \mathrm{TiO}_{2}$ and $\mathrm{P} 3 \mathrm{OT} / \mathrm{TiO}_{2}$ stored in dark and soaked in full sunlight. Seen from Figs. 7A and 7B, with the extension of storing, the photovoltaic parameters, such as $J_{S C}, V_{O C}$, $F F$ and $\eta$, first increase and then decrease, which is due to the fact that the penetration and full contact of $\mathrm{P} 3 \mathrm{HT}$ or $\mathrm{P} 3 \mathrm{OT}$ with $\mathrm{TiO}_{2}$ needs some time. The variety trends of the photovoltaic parameters for both cells are almost similar, after being tested for $168 \mathrm{~h}$ (one week), the $F F, V_{O C}, J_{S C}$ and $\eta$ values decrease about $8.1 \%, 5.8 \%$, $13.5 \%$ and $24.1 \%$, respectively.

As shown in Figs. 7C and 7D, when the hybrid solar cells without being sealed were continuously soaked in a full sunlight, the $V_{O C}$ values kept stable within test $400 \mathrm{sec}$, and $J_{S C}$ values increase within $20 \mathrm{sec}$ and then kept stable. It indicates that the hybrid solar cells have good stability and durability.

\section{Discussion}

In summary, using poly (3-hexylthiophene) (P3HT) or poly (3octylthiophene-2, 5-diyl) (P3OT) as hole conductor, and $\mathrm{TiO}_{2}$ anatase nanocrystal as ultraviolet light absorber and electronic conductor, novel ultraviolet responsive inorganic-organic hybrid solar

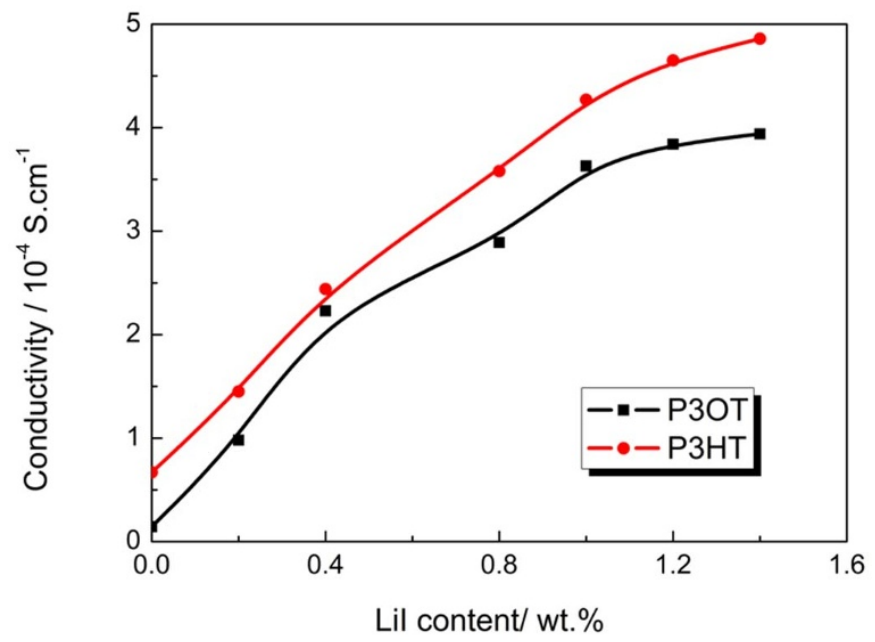

Figure 6 | The influence of LiI contents on the conductivity of polymer solution. cells based on $\mathrm{FTO} / \mathrm{TiO}_{2} / \mathrm{P} 3 \mathrm{HT} / \mathrm{Pt}$ and $\mathrm{FTO} / \mathrm{TiO}_{2} / \mathrm{P} 3 \mathrm{OT} / \mathrm{Pt}$ are fabricated, respectively. Under ultraviolet light irradiation with an intensity of $100 \mathrm{~mW} \cdot \mathrm{cm}^{-2}$, the two hybrid solar cells obtain lightto-electrical energy conversion efficiency of $0.96 \%$ and $0.81 \%$, respectively. Doping ionic salt in the polymer can improve the photovoltaic performance of the solar cells. Two hybrid solar cells doped with 1.0 wt.\% LiI achieve the energy conversion efficiency of $1.28 \%$ and $1.16 \%$, which are increased by $33.3 \%$ and $32.1 \%$ compared to those of the hybrid solar cells without LiI doping, respectively. The photovoltaic performance of the ultraviolet responsive solar cell should be further improved by optimizing components and preparation conditions. No ultraviolet responsive solar cell has been reported so far. The aforementioned results open a novel sunlight irradiation field for solar energy utilization, demonstrate the feasibility of ultraviolet responsive solar cells, and provide a new route for enhancing the photovoltaic performance of solar cells.

\section{Methods}

Materials. Poly(3-hexylthiophene) (P3HT, average Mn 62000, purity 99.995\%) was purchased from Fusol Material Co., Ltd. Taiwan. Ploy(3-octylthiophene-2, 5diyl) (P3OT, average $\mathrm{Mn} \sim 25000$, purity 99.995\%) was purchased from Advanced Technology and Industrial Co., Ltd., Hong Kong. 1, 2-dichlorobenzene (CB), anhydrous ethanol (ETOH), isopropanol, nitric acid $\left(\mathrm{HNO}_{3}\right)$, acetic acid ( $\left.\mathrm{HAc}\right)$, tetrabutyltitanate $\left[\mathrm{Ti}(\mathrm{OBu})_{4}\right]$ and titanium tetrachloride $\left(\mathrm{TiCl}_{4}\right)$ were analytic grade purity and purchased from Shanghai Chemical Agent Ltd, China. Polyethylene glycol with an average molecular weight of 20,000 (PEG-20000) and Triton X-100 were purchased from the same company. All reagents were used without further purification.

A conductive glass plate (FTO glass, fluorine-doped tin oxide over-layer, sheet resistance of $8 \Omega / \square$, purchased from Hartford Glass Co., USA) was cut into $1 \times$ $2 \mathrm{~cm}^{2}$ sheets and used as a substrate for precipitating $\mathrm{TiO}_{2}$ film.

Table 1 The influence of Lil, $\mathrm{Kl}$ on the photovoltaic parameters of the solar cells (under ultraviolet light irradiation of $100 \mathrm{~mW} \cdot \mathrm{cm}^{-2}$ )

\begin{tabular}{lcccc} 
Polymer compositions & $V_{\text {OC }}(\mathrm{V})$ & $J_{S C}\left(\mathrm{~mA} \cdot \mathrm{cm}^{-2}\right)$ & $F F$ & $\eta(\%)$ \\
\hline P3HT & 0.88 & 1.95 & 0.56 & 0.96 \\
P3HT + KI (1.0 wt.\%) & 0.89 & 2.30 & 0.57 & 1.17 \\
P3HT + Lil (O.6 wt.\%) & 0.90 & 2.32 & 0.56 & 1.17 \\
P3HT + Lil (0.8 wt.\%) & 0.89 & 2.45 & 0.56 & 1.22 \\
P3HT + Lil (1.0 wt.\%) & 0.90 & 2.50 & 0.57 & 1.28 \\
P3HT + Lil (1.2 wt.\%) & 0.89 & 2.48 & 0.57 & 1.26 \\
P3HT + Lil (1.4 wt.\%) & 0.90 & 2.38 & 0.56 & 1.20 \\
P3OT & 0.86 & 1.71 & 0.55 & 0.81 \\
P3OT + KI (1.0 wt.\%) & 0.87 & 2.00 & 0.56 & 0.97 \\
P3OT + Lil (1.0 wt.\%) & 0.86 & 2.22 & 0.56 & 1.07 \\
\hline
\end{tabular}



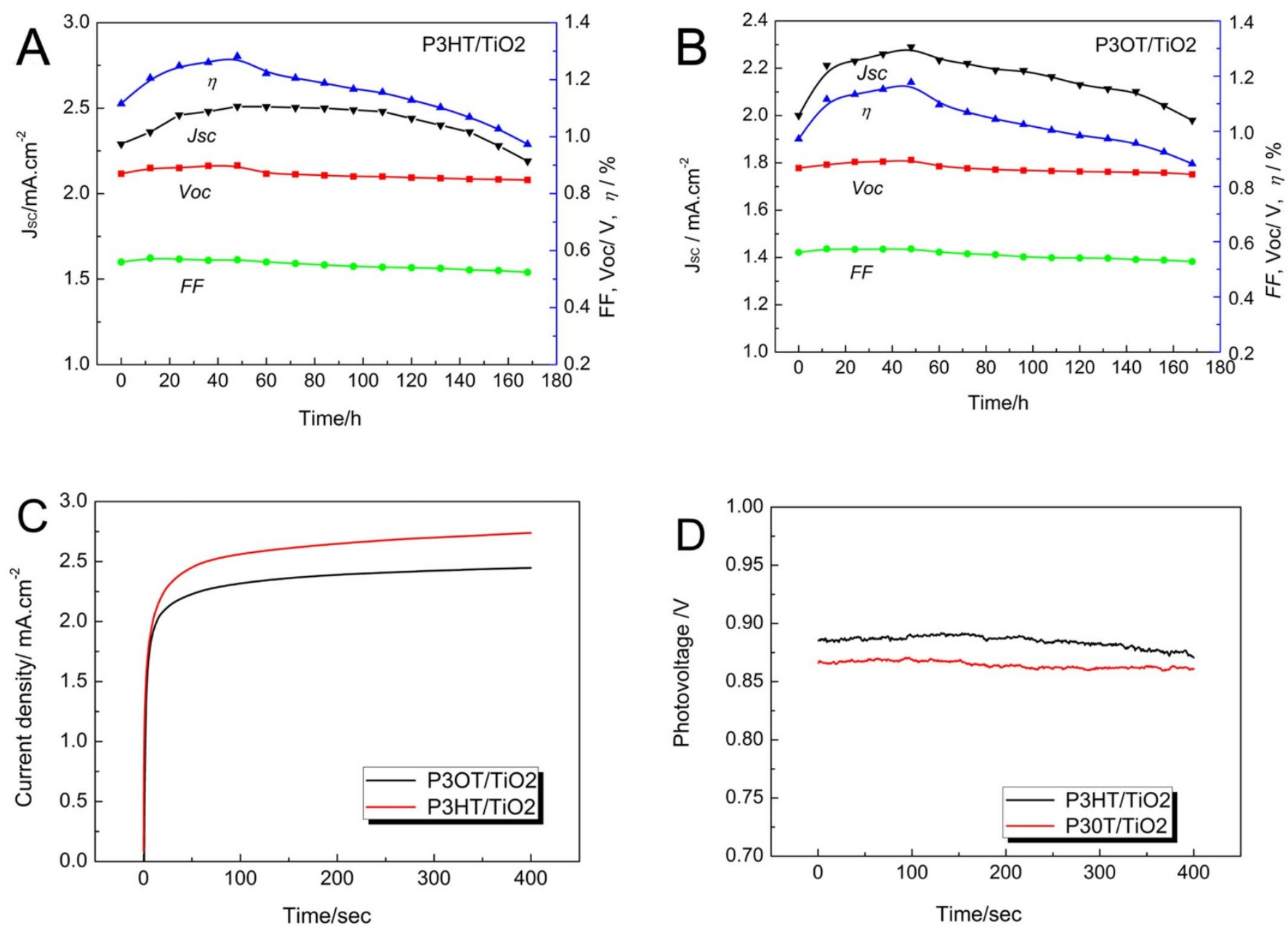

Figure $7 \mid$ The stability of the hybrid solar cells with $\mathrm{P}_{3} \mathrm{HT} / \mathrm{TiO}_{2}$ and $\mathrm{P} 3 \mathrm{OT} / \mathrm{TiO}_{2}$ stored in dark (A) and (B); soaked in full sunlight (C) and (D).

Preparation of $\mathrm{TiO}_{2}$ film. A conductive glass sheet (FTO) was immersed in an isopropanol solution for $48 \mathrm{~h}$ to remove any surface impurities. It was then cleaned in a Triton X-100 aqueous solution, washed with ethanol, and treated with a $50 \mathrm{mM}$ $\mathrm{TiCl}_{4}$ aqueous solution at $70^{\circ} \mathrm{C}$ for $30 \mathrm{~min}$ to produce a good interfacial contact between the $\mathrm{TiO}_{2}$ layer and the conductive glass substrate.

$\mathrm{A} \mathrm{TiO}_{2}$ colloid was prepared as described previously ${ }^{20-22}$. Tetrabutyltitanate $(10 \mathrm{ml})$ was rapidly added to the mixed solution of distilled water $(100 \mathrm{ml})$ and ETOH $(100 \mathrm{ml})$, and white precipitate was formed immediately. The precipitate was filtered using a glass frit and washed with distilled water. Under vigorous stirring, the filter cake was added to aqueous solution $(150 \mathrm{ml})$ containing $1 \mathrm{ml} \mathrm{HNO}_{3}$ and $10 \mathrm{ml}$ $\mathrm{HAc}$ at $80^{\circ} \mathrm{C}$, until the slurry became a translucent blue-white liquid. The blue-white liquid was autoclaved at $200^{\circ} \mathrm{C}$ for $12 \mathrm{~h}$ to form milky white slurry. The resultant slurry was concentrated to $1 / 4$ of its original volume, then PEG-20000 (10 wt.\% slurry) and a few drops of the emulsification agent of Triton X-100 were added to form a $\mathrm{TiO}_{2}$ colloid.

To reduce the recombination of the electrons on the conductive glass with P3HT or P3OT, a thin $\mathrm{TiO}_{2}$ blocking layer was deposited on the FTO glass substrate by immersing the glass in $0.15 \mathrm{M} \mathrm{TiCl}_{4}$ isopropanol solution for $12 \mathrm{~h}$, followed by sintering at $450^{\circ} \mathrm{C}$ for $30 \mathrm{~min}$ in air. Subsequently, two $\mathrm{TiO}_{2}$ layers with particle sizes of $50 \mathrm{~nm}$, thickness of $10 \mu \mathrm{m}$ were coated on the blocking layer by using a doctor blade method, and then sintered at $450^{\circ} \mathrm{C}$ for $30 \mathrm{~min}$ in air. The $\mathrm{TiO}_{2}$ film was immersed in $0.15 \mathrm{M} \mathrm{TiCl}_{4}$ isopropanol solution for $10 \mathrm{~min}$ again, followed by sintering at $450^{\circ} \mathrm{C}$ for $30 \mathrm{~min}$ in air to increase roughness and surface area. The active area of $\mathrm{TiO}_{2}$ film was controlled to be about $0.1 \mathrm{~cm}^{2}$.

Fabrication of hybrid solar cells. P3HT was dissolved in predetermined mass of 1,2dichlorobenzene solvent to form a conductive polymer solution with concentration of $20 \mathrm{~g} \cdot \mathrm{L}^{-1}$ under stirring at $45^{\circ} \mathrm{C}$ for $24 \mathrm{~h}^{23}$. Then under stirring, $25 \mathrm{mg}$ of lithium iodide (LiI) was added in P3HT solution to form a doped P3HT solution (LiI, 1.0 wt.\%).

P3HT was loaded on the $\mathrm{TiO}_{2}$ film by immersing the film in P3HT solution for $24 \mathrm{~h}$. A hybrid solar cell was fabricated by injecting the doped P3HT solution into the aperture between the loaded $\mathrm{TiO}_{2}$ film electrode and a platinum-plated $(\mathrm{Pt})$ counter electrode. The two electrodes were clipped together and cyanoacrylate adhesive was used as sealant. A hybrid solar cell $\mathrm{FTO} / \mathrm{TiO}_{2} / \mathrm{P} 3 \mathrm{HT} / \mathrm{Pt}$ thus was obtained. And the detailed fabrication procedure was described by us elsewhere ${ }^{22}$. For comparison, a hybrid solar cell of $\mathrm{FTO} / \mathrm{TiO}_{2} / \mathrm{P} 3 \mathrm{OT} / \mathrm{Pt}$ also was fabricated by the same method as an $\mathrm{FTO} / \mathrm{TiO}_{2} / \mathrm{P} 3 \mathrm{HT} / \mathrm{Pt}$ solar cell. The schematic structure diagram of the hybrid solar cell is shown in Fig. 1C.

Measurements. The X-ray diffraction (XRD) patterns of the samples were recorded by using an X-ray diffractometer (BRUKER D8, Karlsruhe, Germany) with CuKa radiation $(\lambda=1.5405 \AA$ ). The $2 \theta$ angle of the XRD spectra was recorded at a scanning rate of $3^{\circ} \mathrm{min}^{-1}$. The morphology of $\mathrm{TiO}_{2}$ was observed using a scanning electron microscope (Hitachi S-4800, Japan). The samples for SEM were prepared by spray gold processing (E-1010, Ion Sputter, Hitachi, Japan). The ultraviolet-visible (UVvis) absorption spectra of samples were measured with an ultraviolet-visible spectrophotometer (UV-2550, Shimadzu, Japan). Fourier transform infrared (FTIR) spectra were identified using a spectrophotometer (470 FTIR, Nicolet Nexus, Japan) equipped with an IR data management system. The conductivities of the samples were measured by using model DDB-6200 digitized conductivity meter (Shanghai Reici Instrument Factory, China). The instrument was calibrated with $0.01 \mathrm{M} \mathrm{KCl}$ aqueous solution prior to experiments.

The photovoltaic performance of the hybrid solar cells was determined by measuring photocurrent-photovoltage $(J-V)$ characteristic curve under ultraviolet light irradiation. The ultraviolet light source came from a xenon arc lamp (CHFXM500, Trusttech Co., Ltd, China) with a filter stop (ZWB3, Optical Co., Ltd. Changchun, China) to remove the light with the wavelength higher than $420 \mathrm{~nm}$. This $J-V$ measurement was implemented in ambient atmosphere by using an electrochemical measurement system (CHI660D) to control the voltage and current. The fill factor $(F F)$ and the light-to-electrical energy conversion efficiency $(\eta)$ of the solar cell were calculated according to the following equations ${ }^{2}$ :

$$
\begin{gathered}
\mathrm{FF}=\frac{\mathrm{P}_{\max }}{V_{O C} \times J_{S C}}=\frac{V_{\max } \times J_{\max }}{V_{O C} \times J_{S C}} \\
\eta=\frac{V_{\max } \times J_{\max }}{P_{\text {in }}} \times 100 \%=\frac{V_{O C} \times J_{S C} \times F F}{P_{\text {in }}} \times 100 \%
\end{gathered}
$$


where $J_{S C}$ is the short-circuit current density $\left(\mathrm{mA} \cdot \mathrm{cm}^{-2}\right), V_{O C}$ is the open-circuit voltage $(\mathrm{V}), P_{\text {in }}$ is the incident light power, and $J_{\max }\left(\mathrm{mA}^{\cdot} \mathrm{cm}^{-2}\right)$ and $V_{\max }(\mathrm{V})$ are the current density and voltage at the point of maximum power output in the $J-V$ curves, respectively.

The spectral response of the solar cell was determined by measuring the wavelength dependence of the incident photon-current efficiency (IPCE) and focusing light from one xenon lamp through monochromator (PXJ43B11, Japan) onto the cell. The IPCE value of the solar cell was calculated according to the following equation ${ }^{2}$ :

$$
I P C E=1240 \frac{J_{S C}(\lambda)\left[\mathrm{Acm}^{-2}\right]}{\lambda[\mathrm{nm}] \times P_{\text {in }}(\lambda)\left[\mathrm{Wcm}^{-2}\right]}
$$

1. Cook, T. R. et al. Solar energy supply and storage for the legacy and non legacy worlds. Chem. Rev. 110, 6474-6502 (2010).

2. Hagfeldt, A., Boschloo, G., Sun, L., Kloo, L. \& Pettersson, H. Dye-sensitized solar cells. Chem. Rev. 110, 6595-6663 (2010).

3. Gratzel, M. Photoelectrochemical cells. Nature 414, 338-344 (2001).

4. Linsebigler, A. L., Lu, G. \& Yates, J. Photocatalysis on $\mathrm{TiO}_{\mathrm{n}}$ surfaces: Principles, mechanisms, and selected results. Chem. Rev. 95, 735-758 (1995).

5. Fujishima, A. \& Honda, K. Electrochemical photolysis of water at a semiconductor electrode. Nature 238, 37-38 (1972).

6. Gunes, S., Neugebauer, H. \& Sariciftci, N. S. Conjugated polymer-based organic solar cells. Chem. Rev. 107, 1324-1338 (2007).

7. Sariciftci, N. S., Smilowitz, L., Heeger, A. J. \& Wudl, F. Photoinduced electron transfer from a conducting polymer to buckminsterfullerene. Science $\mathbf{2 5 8}$, 1474-1476 (1992).

8. Huynh, W. U., Dittmer, J. J. \& Alivisatos, A. P. Hybrid nanorod-polymer solar cells. Science 295, 2425-2427 (2002).

9. Previti, F., Patane, S. \& Allegrini, M. Polymer heterostructures with embedded carbon nanotubes for efficient photovoltaic cells. Appl. Surf. Sci. 255, 9877-9879 (2009).

10. Ji, J., Lin, Y., Lu, H., Wang, L. \& Wei, S. Synthesis and photoluminescence of poly(3-hexylthiophene)/titania nanostructured hybrids. Thin Solid Films 511-512, 182-186 (2006).

11. Wang, Y. \& Rubbner, M. F. Stability studies of the electrical conductivity of various poly (3-alkylthiophenes). Synth. Met. 39, 153-175 (1990).

12. Lin, J. \& Dudek, L. Synthesis and properties of poly(2,5-thienylene). J. Polym. Sci. $B$ 18, 2869-2873 (1980).

13. Nicho, M., Hu, H., Lopez-Matab, C. \& Escalantec, J. Synthesis of derivatives of polythiophene and their application in an electrochromic device. Sol. Energy Mater. Sol. Cells 82, 105-118 (2004).

14. Senadeera, G., Kitamura, T., Wada, Y. \& Yanagida, S. Photosensitization of nanocrystalline $\mathrm{TiO}_{2}$ films by a polymer with two carboxylic groups, poly(3thiophenemalonic acid). Sol. Energy Mater. Sol. Cells 88, 315-322 (2005).
15. Yue, G., Wu, J., Huang, Y., Xiao, Y. \& Lan, Z. Iodine/iodide-free and polymer heterojunction-sensitized hybrid solar cell. Funct. Mater. Lett. 5, 1260004 (2012).

16. Kao, C. et al. Doping of conjugated polythiophenes with alkyl silanes. Adv. Funct. Mater. 19, 1906-1911 (2009).

17. McCullough, R., Sristramnagle, T., Williams, S., Lowe, R. \& Jayaraman, M. Selforienting head-to-tail poly(3-alkylthiophenes): new insights on structureproperty relationships in conducting polymers. J. Am. Chem. Soc. 115, 4910-4911 (1993).

18. Sun, B., Jones, J., Burford, R. \& Skyllas-Kazacos, M. Stability and mechanical properties of electrochemically prepared conducting polypyrrole films. J. Mater. Sci. 24, 4024-4029 (1989).

19. Singh, R., Singh, R., Kumar, J., Kant, R. \& Kumar, V. The origin of DC electrical conduction and dielectric relaxation in pristine and doped poly(3hexylthiophene) films. J. Polym. Sci. B 48, 1047-1053 (2010).

20. Wu, J. et al. An all-solid-state dye-sensitized solar cell-based poly(N-alkyl-4-vinylpyridine iodide) electrolyte with efficiency of 5.64\%. J. Am. Chem. Soc. 130, 11568-11569 (2008).

21. Wu, J. et al. A novel thermosetting gel electrolyte for stable quasi-solid-state dyesensitized solar cells. Adv. Mater. 19, 4006-4011 (2007).

22. Wu, J. et al. Application of a polymer heterojunction in dye-sensitized solar cells. Electrochim. Acta 55, 5798-5802 (2010).

23. Zhou, E. et al. Effect of branched conjugation structure on the optical, electrochemical, hole mobility, and photovoltaic properties of polythiophenes. J. Phys. Chem. B 110, 26062-26067 (2006).

\section{Acknowledgments}

The authors acknowledge the financial joint support by the National High Technology Research and Development Program of China (No. 2009AA03Z217) and the National Natural Science Foundation of China (nos. 90922028, U1205112, 50842027).

\section{Author contributions}

J.W. designed the device and experiments, G.Y., Y.X., Z.L. and Q.T. carried out mos experiments. J.W. wrote the manuscript, and all authors discussed the results and contributed to revisions.

\section{Additional information}

Competing financial interests: The authors declare no competing financial interests.

License: This work is licensed under a Creative Commons

Attribution-NonCommercial-ShareALike 3.0 Unported License. To view a copy of this license, visit http://creativecommons.org/licenses/by-nc-sa/3.0/

How to cite this article: $\mathrm{Wu}$, J. et al. An ultraviolet responsive hybrid solar cell based on titania/poly(3-hexylthiophene). Sci. Rep. 3, 1283; DOI:10.1038/srep01283 (2013). 